\title{
Correction to: Regulation of the adaptation to ER stress by KLF4 facilitates melanoma cell metastasis via upregulating NUCB2 expression
}

Dongmei Zhang ${ }^{1,3+}$, Jingrong Lin ${ }^{4 \dagger}$, Yulin Chao ${ }^{1 \dagger}$, Lu Zhang ${ }^{2}$, Lei Jin ${ }^{1}, \mathrm{Na} \mathrm{Li}^{3}$, Ruiping He ${ }^{1}$, Binbin $\mathrm{Ma}^{2}$, Wenzhi Zhao ${ }^{2^{*}}$ and Chuanchun Han ${ }^{1 *}$

Correction to: J Exp Clin Cancer Res 37, 176 (2018). https://doi.org/10.1186/s13046-018-0842-z

Following publication of the original article [1], the authors identified some minor errors in Figs. 1, 3, 4 and 6, specifically:

Figure 1a: incorrect image was used for the migration image of Mel-CV.

Figure 3e: incorrect images were used for the migration images of Mel-RM shRNA CTR and A375 shKLF4-2.

Figure 4i: the KLF4 western blot band of shRNA KLF4 TM $36 \mathrm{~h}$ group was incomplete.

Figure 4i: incorrect image was used for the band of NUCB2.

Figure 6f: incorrect image was used for the migration image of KLF4 KO + NUCB2 TM 36h group.

The authors provided the Journal with the original data files. The corrected figures are given here. The corrections do not have any effect on the final conclusions of the paper. The original article has been corrected.

\begin{abstract}
Author details
'Institute of Cancer Stem Cell, Dalian Medical University, Dalian 116044, China. ${ }^{2}$ Department of Orthopedics, Second Affiliated Hospital, Dalian Medical University, Dalian 116044, China. ${ }^{3}$ Department of Physiology, College of Basic Medical Sciences, Dalian Medical University, Dalian 116044, China. ${ }^{4}$ Department of Dermatology, the First Affiliated Hospital, Dalian Medical University, Liaoning 116027, China.
\end{abstract}

Published online: 07 December 2021

\section{Reference}

1. Zhang D, Lin J, Chao Y, et al. Regulation of the adaptation to ER stress by KLF4 facilitates melanoma cell metastasis via upregulating NUCB2 expression. J Exp Clin Cancer Res. 2018;37:176. https://doi.org/10.1186/ s13046-018-0842-z.

The original article can be found online at https://doi.org/10.1186/s13046018-0842-z.

*Correspondence: drzwz@163.com; hanchuanchun@163.com

†Dongmei Zhang, Jingrong Lin and Yulin Chao contributed equally to this work.

${ }^{1}$ Institute of Cancer Stem Cell, Dalian Medical University, Dalian 116044 , China

2 Department of Orthopedics, Second Affiliated Hospital, Dalian Medical University, Dalian 116044, China

Full list of author information is available at the end of the article

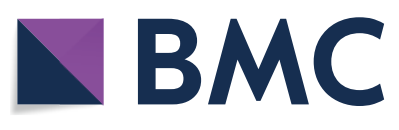

(c) The Author(s) 2021. Open Access This article is licensed under a Creative Commons Attribution 4.0 International License, which permits use, sharing, adaptation, distribution and reproduction in any medium or format, as long as you give appropriate credit to the original author(s) and the source, provide a link to the Creative Commons licence, and indicate if changes were made. The images or other third party material in this article are included in the article's Creative Commons licence, unless indicated otherwise in a credit line to the material. If material is not included in the article's Creative Commons licence and your intended use is not permitted by statutory regulation or exceeds the permitted use, you will need to obtain permission directly from the copyright holder. To view a copy of this licence, visit http://creativecommons.org/licenses/by/4.0/. The Creative Commons Public Domain Dedication waiver (http://creativecommons.org/publicdomain/zero/1.0/) applies to the data made available in this article, unless otherwise stated in a credit line to the data. 


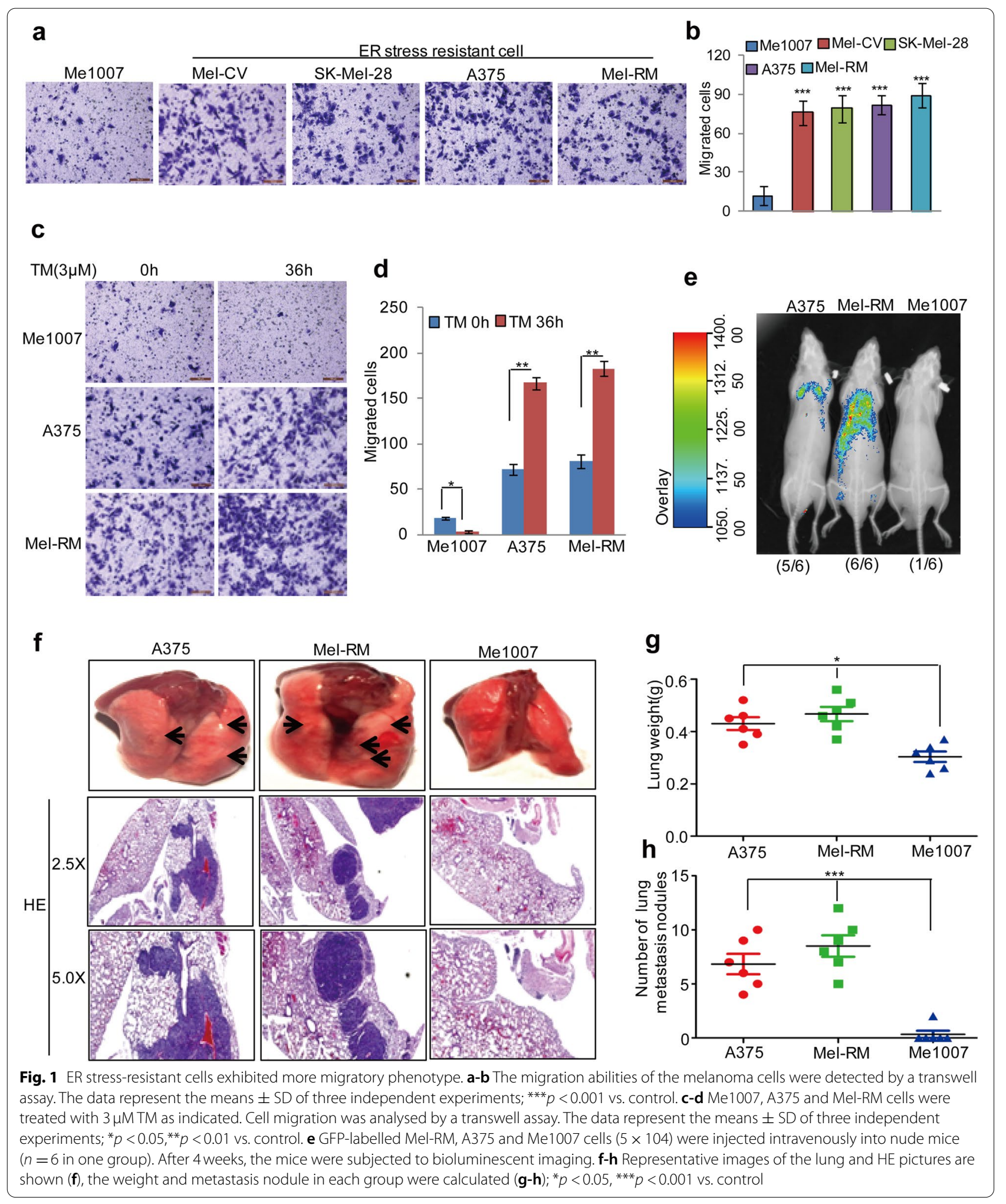




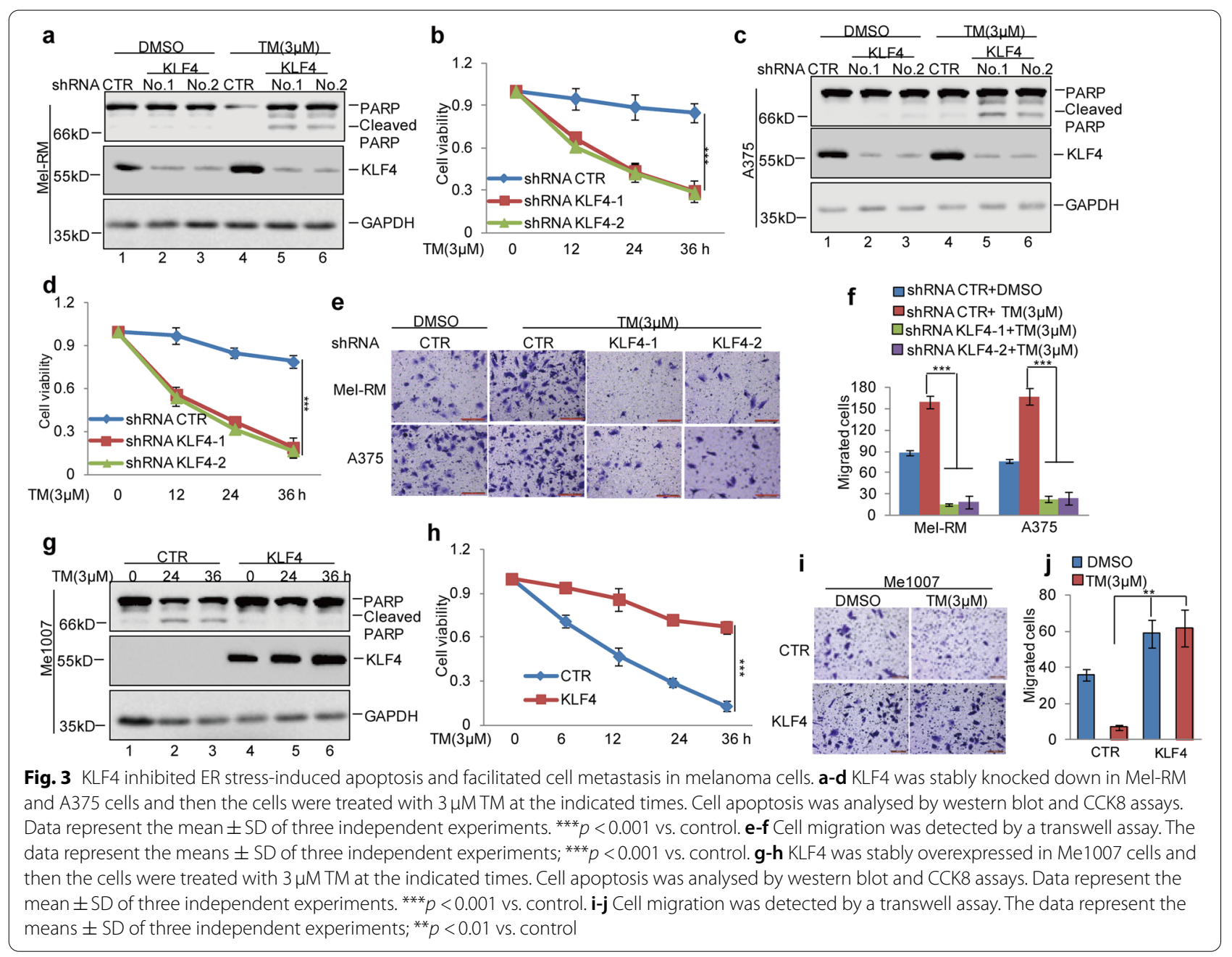




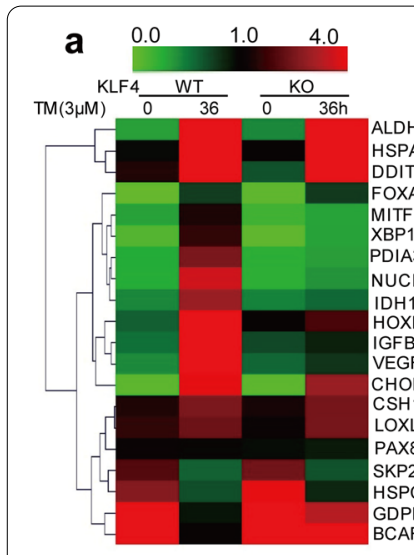

e
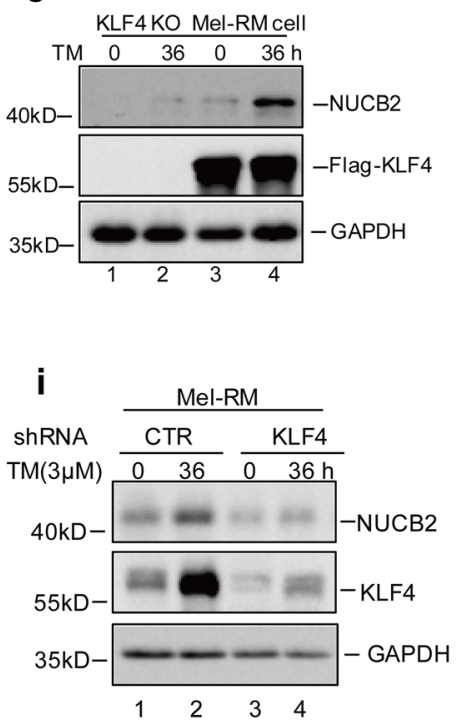

b

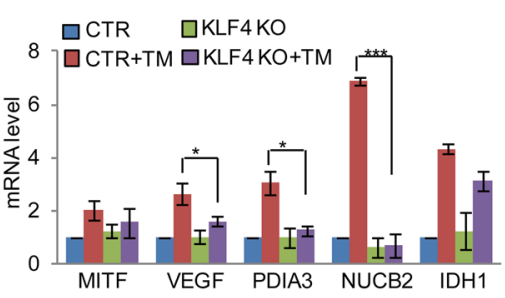

C

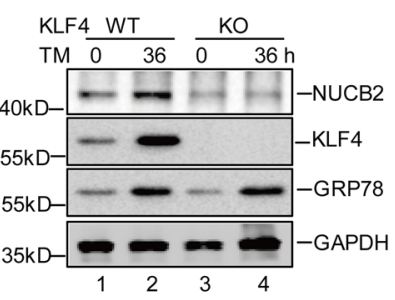

d

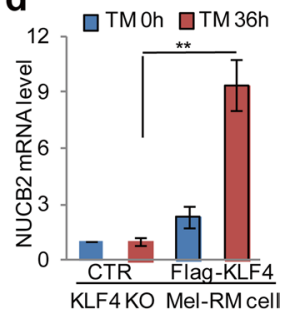

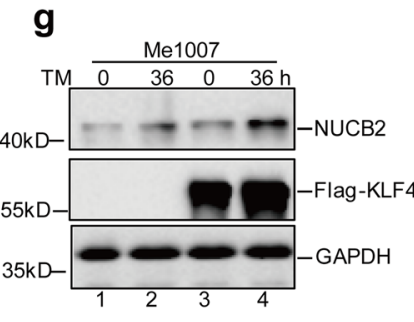

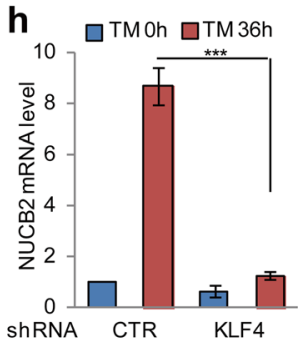

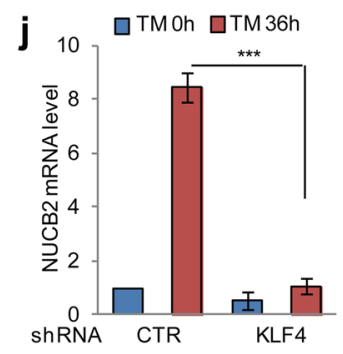

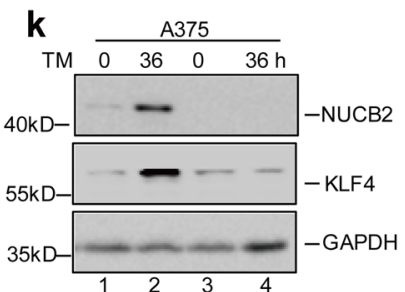

Fig. 4 KLF4 upregulated NUCB2 expression in melanoma cells. a KLF4 WT or KO Mel-RM cells were treated with $3 \mu M$ TM at the indicated times. Gene expression profiles were obtained by RNA sequencing analysis. b The expression levels of MITF, VEGF, PDIA3, NUCB2 and IDH1 were analysed by q-RT-PCR. The data represent the means \pm SD of three independent experiments; ${ }^{*} p<0.05,{ }^{* * *} p<0.001 \mathrm{vs}$. control. c The protein levels of KLF4 and NUCB2 were detected by western blot. $\mathbf{d}$-e Flag-KLF4 and empty vector were individually transfected into KLF4 KO Mel-RM cells and the cells were treated with $3 \mu \mathrm{M}$ TM at the indicated times. The expression levels of NUCB2 were analysed by q-RT-PCR and western blot assays. The data represent the means \pm SD of three independent experiments; ${ }^{* *} p<0.01$ vs. control. $\mathbf{f}-\mathbf{g}$ The Me1007 cells with or without KLF4 overexpression were treated using $3 \mu \mathrm{M}$ TM at the indicated times. The expression levels of NUCB2 were analysed by q-RT-PCR and western blot assays. The data represent the means \pm SD of three independent experiments; ${ }^{* * *} p<0.001$ vs. control. h-k Mel-RM and A375 cells with or without KLF4 knockdown were treated with $3 \mu \mathrm{M}$ TM at the indicated times. The mRNA and protein levels of NUCB2 were detected by q-RT-PCR and western blot assays. Data represent the mean $\pm S D$ of three independent experiments. ${ }^{* *} p<0.001$ vs. control 


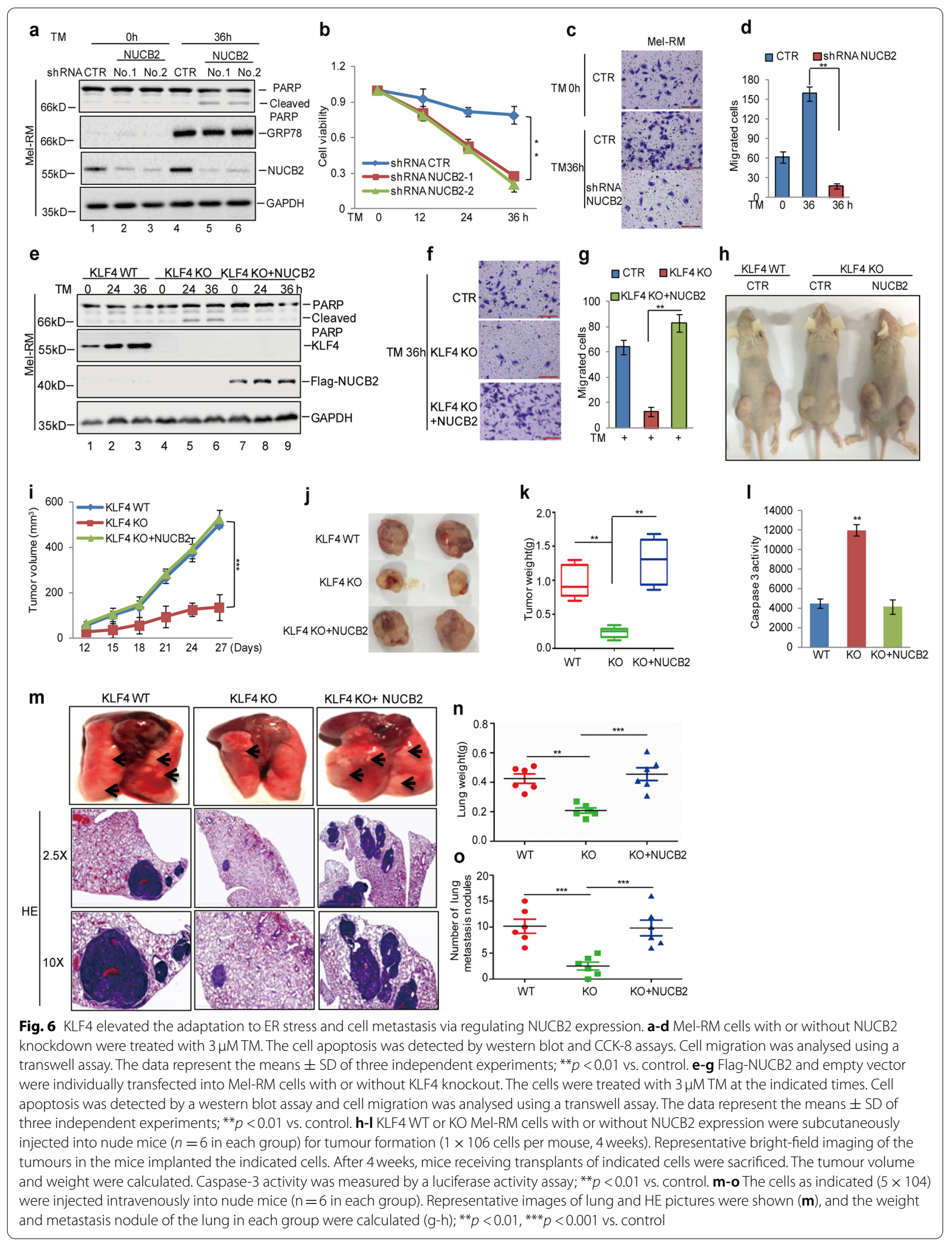

